\title{
Determinants of Leverage for Manufacturing Firms Listed in the KOSDAQ Stock Market
}

\author{
Hanjoon $\mathrm{Kim}^{1^{*}}$ \\ ${ }^{1}$ Dept. of Business Administration, Hoseo University \\ 한국 $\mathrm{KOSDAQ}$ 상장기업들의 자본구조 결정요인 분석 \\ 김한준 $^{*}$ \\ ${ }^{1}$ 호서대학교 사회과학대학 경영학과
}

\begin{abstract}
This study investigates empirical issues that have received little attention in the previous research in the Korean capital market. It is to find any financial determinants on the capital structure for the firms listed in the KOSDAQ(Korea Securities Dealers Automated Quotation). Another test is performed to find any possible discriminating factors by utilizing a robust methodology, which may distinguish between the firms belonging the 'prime section' and the 'venture section' in terms of their financial aspects. Moreover, the null hypothesis that the changing trend or movement of a firm's capital structure with respect to its industry mean (or median) may be random, is also tested. For the book-value based debt ratios, size(INSIZE), growth(GROWTH), Market to book value of equity(MVBV), volatility(VOLATILITY), market value of equity (MVE) and section dummy (SECTION) showed their statistically significant effects on the book-value based leverage ratios, respectively, while size(INSIZE), growth(GROWTH), market value of equity(MVE), beta(BETA) and section dummy (SECTION) showed their statistically significant effects on the market-value based leverage ratios. This study also found an interesting result that a firm belonging to each corresponding industry has a tendency for reversion toward its mean and median leverage ratios over the five-year tested period.
\end{abstract}

요 약 본 연구는 국내 자본시장에서 지금까지 상대적으로 낮은 관심을 받아왔던 KOSDAQ 상장기업들의 재무적 특성 분석(자본구조 포함에 관한 실증적인 연구이다. 본 연구에서는 KOSDAQ 기업들(우량기업부와 벤처기업부 소속) 에 대한 상대적으로 포괄적인 가설검정을 실행하였다. 첫 번째 가설은 동 상장회사들의 자본구조(부채) 결정에 영향 을 미칠 수 있는 설명변수의 통계학적인 분석이다. 다중 회귀식을 이용한 결과, 장부가 기준의 종속변수에 대한 영향 력과의 관계에서, 자산크기, 성장성, 시가-장부가 비율, 변동성, 시가총액, 그리고 KOSDAQ 내의 소속부에 대한 더미 변수 들이 통계학적인 유의성을 보였고, 시장가 기준의 종속변수에 대한 설명변수들의 영향력은 자산크기, 성장성, 시 가총액, 체계적 위험의 대용치인 베타계수, 그리고 소속부 더미변수에서 나타났다. 두 번째 가설검정은 로지스틱 모델 을 이용한 소속부 분류 기준상, 해당 기업들의 재무적인 특성분석 검정이었으며, 마지막 분석은 해당 기업들의 산업 별 평균 부채비율로서의 '회귀성'관련 검정이었다. 로지스틱 회귀식 결과와 관련하여 기업들의 재무특성 중, 수익성, 자산크기, 시가대비 장부가 비율, 그리고, 외국인 지분률이 각각 높을수록 벤처기업부 대비, 우량기업부로 분류될 확 률이 높음을 알 수 있었으며, Fisher exact 확률검정을 이용한 해당 기업들의 부채회귀성 가설에 대한 검정 결과, 산 술평균치와 중앙값 각각을 기준으로 매 5년 주기로 평균 부채비율로의 회귀성이 통계적으로 판명되었다. 이는 Bowen et al.(1982)의 미국 기업들 대상의 검정결과와 일치하며, 평균부채 회귀성의 자본선진국의 일반 경향이 본 연구대상인 KOSDAQ 기업 대상의 연구에서도 발견될 수 있었다는 점에도 기여도가 있다고 판단한다.

Key Words: KOSDAQ, Capital Structure, Financial Characteristics, Fisher Exact Test, Mean Reversion

\footnotetext{
This work was supported by the fund provided by Hoseo University :[2011-0084].

${ }^{*}$ Corresponding Author: Kim, Hanjoon

Tel: +82-10-4797-5777 email: khj723@hoseo.edu

Received April 10, 2012

Revised (1st May 2, 2012, 2nd May 8, 2012)
}

Accepted May 10, 2012 


\section{INTRODUCTION}

This study investigates empirical issues that have received little attention in the previous research in the Korean capital market. It is to find any financial determinants on the capital structure for the firms listed in the KOSDAQ (Korea Securities Dealers Automated Quotation). There has been more academic research on the findings of possible determinants for the listed companies in the KOSPI(Korea Composite Stock Price Index), compared to those for the firms belonging to the KOSDAQ[1]. In this paper, coupled with one of the hypotheses to test for any financial attributes or characteristics on the capital structure, another test is performed to find any possible discriminating factors by utilizing a robust methodology, which may discriminate between the firms belonging the 'prime section' and the 'venture section' in terms of their financial attributes. Moreover, the null hypothesis that the reverting trend or movement of a firm's capital structure with respect to its industry mean (or median) may be random, is also tested for the sample firms listed in the KOSDAQ stock market.

It seems to be plausible to interpret the current situations implying why there have been relatively few studies concerning the firms listed in the KOSDAQ, by understanding the following reasons: First, the Korean capital market has been classified as an emerging one, taking into account of its relatively short history and medium size in comparison with its counterparts, advanced capital markets. Accordingly, priority within the Korean domestic capital markets, may be given to the researches on the firms belonging to the KOSPI rather than those of the firms belonging to the KOSDAQ. Second, many practitioners including equity analysts in investment banks or domestic securities corporations may be less motivated to analyze and value at least some of the firms classified into the KOSDAQ, due to their frequent accounting scandals and moral hazard at management level. Third, due to the shorter history and the smaller size of the KOSDAQ firms than those of the firms in the KOSPI, less qualitative and quantitative data to be analyzed seem to be available, coupled with less reliable and consistent financial data as described in Errunza[2] and $\operatorname{Kim}[3]$.

Given the dynamically changing global economic circumstances including the bilateral agreements such as the Korea-U.S. FTA(free trade agreement) and the Korea-EU FTA, increasing number of large foreign firms are expected to establish their new subsidiaries in the Korean domestic market. Conversely, major export-driven Korean companies are currently organizing their new foreign-based entities using managerial strategies such as minimizing currency-risk exposure[4]. Therefore, for the benefits of theory and practice, the results obtained in this study would be useful for multinational corporations in both advanced capital and emerging capital markets (including Korea) when considering to establish their long-term capital structures.

\section{PREVIOUS LITERATURE}

There have been extensive researches centered on the firm's capital structure, leverage or debt ratio, since the publication of the original and renowned article by Modigliani-Miller (M\&M) presenting that there would be no optimal capital structure under the assumptions of perfect capital markets with no taxes[5]. Since then, many studies have sought to find determinants which may affect to find optimal capital structure assuming the imperfect capital markets of the practical world.

The study by Remmers et al.[6] presented that industry was not a determinant of corporate leverage ratios in the manufacturing sectors in the U.S., while Scott[7] employed the multiple comparison procedure to find any significant difference between each pair of the sample industries. Once Scott obtained the resulting one-way analysis of variance(ANOVA) inference against the null hypothesis of no industry influence, he performed a multiple comparison test and concluded that the inter-industry differences were pervasive in the capital structure of U.S. firms. Toy et al.[8] found other statistically significant determinants of capital structure, such as growth, profitability, and international risk in their study.

Myers[9] presented that the optimal policy for maximizing the market value of a firm with no corporate taxes is not to issue debt at all, resulting in the "under-investment problem" by the shareholders of the firm. He theorized that real options, which may engender positive investment opportunities, seemed to have 
limitations as security for debt claims due to the thin and imperfect secondary markets. Ferri and Jones[10] hypothesized to test the relationships between a firm's capital structure and its industry class, size, business risk, and operating leverage as possible determinants of capital structure. The variable to proxy for Industry class was found to be weakly, but statistically significant. Moreover, size and operating leverage seemed to be associated curvilinearly, and linearly with negative slope, respectively, relating to the debt ratios at book value. Bradley at el.[11] showed that a firm's market value based leverage ratio remained inversely related to the volatility of its earnings and financial distress proxied by research \& development (R\&D) and advertising expenses. But, it was positively related to the previously mentioned non-debt tax shields, regardless of the inclusion of industry dummy variables in the model. The concept of the "secured debt" hypothesis argued in previous finance literature was also adopted to interpret this perverse and positive relationship between non-debt tax shields and financial leverage. The study performed by Bowen et al.[12] demonstrated negative and significant relationships between the level of non-debt tax shields and average debt ratio at the industry level across most sample years. Moreover, they tested the tendency of mean reversion of the sample firms belonging to their respective industries in terms of capital structure based up the 5-year and 10 year time period. Kester[13] compared the capital structures between U.S. and Japanese corporations. He found that there were significant differences in capital structure between the two countries on a book value basis, after controlling for other factors such as profitability, risk, growth, and size, as well as industry classification. Most of the mature and heavy Japanese industries had higher leverage than their U.S. counterparts at either book- or market-value basis.

A new approach, covering a broad spectrum of possible determinants of capital structure, was tested by Titman and Wessels[14]. They presented that profitability had a significantly negative relationship with market value based debt ratios, while growth, non-debt tax shields, volatility, and asset structure were not generally associated with the various measures of leverage. Moreover, small sized firms had more short-term debt financing than large firms, due to the high transaction costs when issuing long-term securities. Barclay et al.[15] also performed an extensive empirical study to investigate the determinants of corporate leverage and dividend policies from the data of 6,780 U.S. companies for the years 1963 to 1993. Especially, a firm's market-to-book ratio as a proxy for investment opportunities showed a statistically significant negative relationship with leverage ratio. They found that there was a statistically significant positive relationship between a firm's leverage and its earnings increase to proxy for signaling effects.

Cho[16] tested financial characteristics which may discriminate successful group from unsuccessful group sampled by the 51 KOSDAQ firms. By employing two separate tests such as Wilcoxon rank-sum test and logit analysis, this study found that all the tested variables excluding equity turnover ratio, showed their statistically significant effects to discriminate between the two groups in the former test result. Moreover, the EBIT(earinings before interest \& taxes) ratio was significant at 5\% level. Bancel and Mittoo[17] investigated as the sample data, 16 European countries including the U.K. and France to find whether managers in those countries agreed with US managers in what the determinants of capital structure are. The null hypothesis that they agreed was accepted. The study by Deesomsak et al.[18], examined the determinants of corporate leverage in the Asia Pacific region, including Malaysia, Thailand, Singapore, and Australia, during the period of 1993-2001. They presented that the firm size effect on leverage was statistically significant and positive for most countries in the region after the 1997 Asian financial crisis. Across all sample countries for the entire period studied, non-debt tax shield, liquidity, and share price performance, among several explanatory variables tested, showed their statistically significant effects on debt ratios. The study performed by Kim and Berger[19], investigates two prolonged controversial issues concerning Korean chaebols vs. non-chaebols. One of the issues investigated is whether firms belonging to the chaebol in Korea have different market-value based debt ratios than their counterparts not belonging to the chaebol. If this is so, there are several managerial implications. Results indicate that, for the period studied, firms in the chaebol did have a higher mean leverage than their counterparts. The other issue addressed, used logistic regression analysis to determine that firms belonging to the chaebol appeared to possess different levels of the financial 
characteristics, in comparison with firms not belonging to the chaebol. By utilizing the logistic regression model, Pank and Kang[20] tested to develop falling prediction model for the firms listed in KOSDAQ. They employed explanatory variables in terms of growth, liquidity, leverage, profitability, and activity. They found that the accuracy of classification of the models by year was between $76.5 \%$ and $77.5 \%$, while the mean model showed its accuracy between $70.6 \%$ and $83.4 \%$. The study performed by $\operatorname{Kim}[21]$, is to perform several major analyses to find any differences in the leverage between the pre- and post-period of the Asian financial or currency crisis. It was found that firms belonging to the chaebol in Korea maintained higher average book-value and market-value based debt ratios, relative to their counterparts not belonging to the chaebol across all of the tested models. This study identified that there were no differences in the explanatory variables included, between the tested models (that is, without and with including the present value of an operating lease) related to each debt ratio.

[Table 1] Major Selected Studies on the Leverage

\begin{tabular}{|l|l|}
\hline \multicolumn{1}{|c|}{ Study } & \multicolumn{1}{|c|}{ IDV } \\
\hline Toy et al.(1974) & $\begin{array}{l}\text { growth, profitability, and } \\
\text { international risk }\end{array}$ \\
\hline Ferri \& Jones(1979) & $\begin{array}{l}\text { Industry, size and operating } \\
\text { leverage }\end{array}$ \\
\hline Bradley et al.(1984) & $\begin{array}{l}\text { earnings financial distress } \\
\text { and non-debt tax shields }\end{array}$ \\
\hline Kester (1986) & $\begin{array}{l}\text { profitability, risk, growth, and } \\
\text { size, as well as industry } \\
\text { classification. }\end{array}$ \\
\hline Barclay et al.(1995) & $\begin{array}{l}\text { market-to-book ratio and } \\
\text { earnings }\end{array}$ \\
\hline Deesomsak et at.(2004) & $\begin{array}{l}\text { size, non-debt tax shield, } \\
\text { liquidity, and share price } \\
\text { performance }\end{array}$ \\
\hline Kim \& Berger(2008) & Industry and profitability \\
\hline
\end{tabular}

(Note)IDV: Statistically significant independent variables found in each respective study

\section{DATA AND METHODOLOGY}

\subsection{Data Collection}

As described, this research employed the sample firms listed in the KOSDAQ during the 5-year period from the years of 2006 to 2010, a period chosen specifically due to the relatively short history of the particular market. Moreover, this research used more strict criteria than those in most of the previous literature in order to obtain more reliable and representative sample firms as illustrated in [Table 2].

\section{[Table 2] The Sampling Criteria}

1. The corporations were included in the New KisValue database for Korea.

2. The corporations were listed in the KOSDAQ at the end of December 2010.

3. The corporations should be included in either the 'prime' or the 'venture' section in the KOSDAQ, to be selected for the sample data.

4. All the data for each corporation were available for at least 5 years (2006-2010).

5. Financial and regulated industries were not included in the sample.

This study screened only corporations classified into the 'prime' and the 'venture' sections in the KOSDAQ in comparison with the firms classified into the 'middle-stage' and the 'new growth' sections according to the regulations of the Korea Exchange. The rationale to select the sample firms belonging to these particular sections is as follows: (1) Larger corporations in size were likely to provide more reliable and consistent financial data, especially from a country with a less developed capital market. Similar arguments were made in Errunza[22] and Kim and Lee[23]. Even if the Korean capital market seems to be regarded as closer or near-advanced markets, those firms listed in the KOSDAQ have their relatively shorter domestic history than that of the firms listed in the Korea Exchange, as describe in the previous section. Therefore, more rigid or parsimonious set of the sample data for the KOSDAQ firms may be necessary to obtain more robust or reliable results. (2) In less efficient capital markets, information asymmetries between management and outside investors, as presented in Myers and Majluf[24], may be less severe for relatively large and long history of corporations in the section such as 'prime' and 'venture' ones, among the four sections, taking also into account 
the larger number of shareholders and higher proportion of minority interests, as similarly described in Kester[25].

\subsubsection{Independent Variables(IDVs)}

In this study, ten independent variables(IDVs) were employed for the domestic manufacturing firms listed in the KOSDAQ stock market to apply to the sample data, besides dummy variables such as industry classifications, section, and time as possible explanatory variables to affect leverage. These variables may be the generally used proxies, although sometimes they showed conflicting results in the previous researches.

First, profitability in this study was measured by the ratio of earnings before interest and taxes (EBIT) to book value of assets at the fiscal year-end of each firm in every sample year. A potential problem arising from a spurious correlation between the market value based leverage ratios and profitability as an independent variable may be reduced to a large extent after being scaled by book value of assets instead of market value of assets, as also described in Bradley[26] and Kim and Berger[27]. Profitability was the only statistically significant explanatory variable among other major IDVs employed to affect the level of leverage as tested in Kim and Berger[28]. Second, the proxy for size was total assets at the end of the fiscal year-end for each sample firm, which has then been taken the natural logarithm. Small sized firms may be more deviate from their target capital structures than large sized firms, due to higher adjustment costs in external financing when raising new equity and retiring debt presented in Barclay et al.[29]. Third, a proxy for growth was calculated by using annual geometric average in sales during the sample period (2006 to 2010) for each sample firm. This proxy may be associated with Myers' theory that firms having more opportunities in investments in intangible assets may face higher degree of agency costs of debt described in Myers[30]. By employing market-to-book ratio as a proxy for growth, Barclay et al.[31] found that growth companies tended to have significantly lower long-term debt ratio than companies possessing less investment opportunities. Fourth, business risk, which was examined in many previous studies, was proxied by the 'volatility' defined by the New KisValue database as follows: The standard deviation of annual stock returns times the square root of total number of trading days during a year. For example, if the standard deviation of annual stock returns is equal to ' 1 ' and the total number of trading days are 252 , annual 'volatility' employed in this study is calculated as $1 \mathrm{x}$ $(252) 1 / 2=15.87$. In this particular research, the measurement of a systematic risk, beta, was also employed to test for its relation to the leverage for the sample firms.

Moreover, it is particular interesting to test for the relationship between the degree of ownership by major shareholders and the leverage of a firm listed in KOSDAQ. Due to the shorter history and smaller size of firms in terms of market value or assets, the degree of control or supervision against management, may be less weighed or directed by the external parties, given the relatively higher frequencies of management moral hazard including accounting scandals, etc. This moral hazard may result in excessive usage of debt, which thereby increase agency cost of debt between the debtholders and the shareholders in a firm. On the other hand, higher degree of 'foreign' ownership may protect from any possible mismanagement of a firm in KOSDAQ by enforcing the controlling function against any morall hazard as well. Coupled with other explanatory variable such as the market- to book-value of equity(MVBV), three dummy variables were employed as proxies for industry, section, and time to determine the levels of leverage. Finally, free cash flow(FCF) employed in this study is defined as [earings after corporate taxes - (net changes of the amount of assets during a fiscal year)].

\subsubsection{Dependent Variables(DVs)}

This study utilized as the dependent variables both the market-value and the book-value based leverage ratios. The former (=MVLEV1) was defined by the ratio of total liabilities at book value to total liabilities plus total preferred stock at book value plus common equity at market value, while the latter (=BVLEV1) was calculated based upon the ratio of total liabilities divided by total assets. The common equity at market value was determined by multiplying the closing market price of common stock on the last trading day by total number of common shares outstanding at the fiscal year-end of each sample firm during the period of 2006 to 2010. In particular, the market value based debt ratio, may be a more practical 
representation for the Korean companies in which substantial differences may exist between the market and book value of real assets Kim and Berger[32]. Moreover, market-value based debt ratio, may be a better specification from the theoretical perspective of an optimal capital structure in modern finance theory.

Regarding the five-year sample period covered in this particular study, Bowen et al.[33] presented that leverage ratios tend to revert to their mean (or average) in every five year interval. Therefore, the 5 year sample period (2006 - 2010) has been employed to test for the determinants of capital structure in this particular study to find any determinants of leverage for the sample firms belonging to KOSDAQ.

The second proxy dependent variable(BVLEV2) as times interest earned (=earnings before interest and taxes(EBIT)/interest expense) has been employed to take into account the fact that this ratio has been particularly paid attention to most domestic firms in Korea for its practical usage, since the 'Asian financial crisis or unstability' period in 1997 and 2008. This particular variable (=BVLEV2) may provide more crucial quantitative measure to estimate the possibility of a firm's bankruptcy.

Finally, this study employed the two lags of leverage as the dependent variables for both at market-value basis(MDIFFBVLEV) and book-value basis(DIFFBVLEV) to reduce ant possible autocorrelation in the sample data as described in Greatrex[34].

[Table 3] Definition of the Independent Variables

\begin{tabular}{|c|c|l|}
\hline Definition & Proxy Variable & \multicolumn{1}{|c|}{ Measurement } \\
\hline Size & INSIZE & $\begin{array}{l}\text { Natural Log of Book } \\
\text { value of assets at the } \\
\text { fiscal year-end }\end{array}$ \\
\hline Profitability & PFT & $\begin{array}{l}\text { Earnings before interest } \\
\text { and taxes(EBIT) / Book } \\
\text { value of assets at the } \\
\text { fiscal year-end }\end{array}$ \\
\hline Volatility & VOLATILITY & $\begin{array}{l}\text { Standard deviation of } \\
\text { annual stock returns } \\
\text { times the square root of } \\
\text { total number of trading } \\
\text { days during a fiscal } \\
\text { year }\end{array}$ \\
\hline $\begin{array}{c}\text { Market value of } \\
\text { equity }\end{array}$ & MVE & Market value of equity \\
\hline
\end{tabular}

\begin{tabular}{|c|c|l|}
\hline $\begin{array}{c}\text { Market- to } \\
\text { book- value of } \\
\text { equity }\end{array}$ & MVBV & $\begin{array}{l}\text { Market value of equity / } \\
\text { book value of equity }\end{array}$ \\
\hline Growth & GROWTH & $\begin{array}{l}\text { Annual average compound } \\
\text { growth rate in sales } \\
\text { during the sample period }\end{array}$ \\
\hline $\begin{array}{c}\text { Foreign } \\
\text { ownership }\end{array}$ & FOS & $\begin{array}{l}\text { Foreign ownership of } \\
\text { each KOSDAQ sample } \\
\text { firm }\end{array}$ \\
\hline $\begin{array}{c}\text { Major } \\
\text { shareholders' } \\
\text { ownership }\end{array}$ & MAJORSHARE & $\begin{array}{l}\text { Major shareholders' } \\
\text { owrnership of KOSDAQ } \\
\text { sample firm }\end{array}$ \\
\hline Beta & BETA & $\begin{array}{l}\text { Systematic risk of a } \\
\text { sample firm }\end{array}$ \\
\hline Free cash flow & FCF & $\begin{array}{l}\text { Earings after corporate } \\
\text { taxes - (net changes of } \\
\text { the amount of assets } \\
\text { during a fiscal year) }\end{array}$ \\
\hline Section & SECTION & $\begin{array}{l}\text { Dummy variable } \\
\text { categorizing between } \\
\text { the 'prime section'(=1) } \\
\text { and the 'venture' } \\
\text { section (=0) }\end{array}$ \\
\hline
\end{tabular}

There are three primary hypotheses tested in this particular study, regarding any possible financial characteristics on the capital structure of a firm listed in the KOSDAQ market.

Regarding the first hypothesis, this study performed time-series cross-sectional ordinary least squares(OLS) to regress the DVs as the leverage ratios on the explanatory variables, separately for the sample firms. The hypothesis on this issue is as follows in order to find any financial determinants of the capital structure for the firms listed in the KOSDAQ:

\section{$<$ Hypothesis 1> \\ H0: The firms listed in the KOSDAQ shows no statistically significant financial characteristics affecting leverage in this particular study. \\ H1: The firms listed in the KOSDAQ shows at least, one statistically significant financial characteristics affecting leverage ratio in this study.}

The model described below contains the eligible variables (not all of which were chosen by the stepwise process, as reported in the next section):

Leverageit $=\mathrm{b} 0+\mathrm{b} 1$ PFTit + b2INSIZEit

+ b3GROWTHit + b4MVBVit 


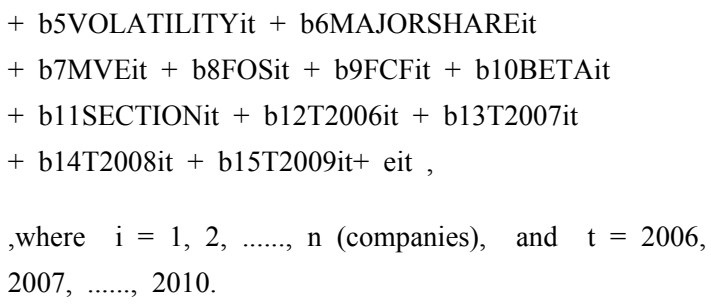

LEVERAGE = Book-value or market-value based leverage ratios previously defined as BVLEV1, BVLEV2, DIFFBVLEV, MVLEV, and MDIFFBVLEV.

SECTION $=1$ if a firm belongs to a 'prime' section. 0 , otherwise.

$\mathrm{T} 2006=1$ if the year $=2006$.

0 , otherwise.

$\mathrm{T} 2007=1$ if the year $=2007$.

0 , otherwise.

$\mathrm{T} 2008=1$ if the year $=2008$.

0 , otherwise.

$\mathrm{T} 2009=1$ if the year $=2009$.

0 , otherwise.

$\mathrm{e}_{\mathrm{it}}$ is the error term assumed to be normally distributed, homoscedastic, and, after a check for autocorrelation which came out not significant, independent.

Moreover, this study separately used the stepwise regression procedure in the multiple regression analysis to take advantage of its ability to derive a parsimonious model that was relatively free of multi-collinearity, in the sense that every variable in the final model would be guaranteed to add significant incremental predictive value as also described in Kim and Berger[35].

Second, subsequent to the results obtained from the first hypothesis, it may interesting and useful from a managerial perspective to further investigate which financial characteristics of a Korean firm increase the probability that the firm is classified as a 'prime' section in comparison to a firm classified as a 'venture' section,

A relevant and robust-result test to find any attributes to distinguish between the firms belonging to the 'prime' section and the 'venture' section according to the KOSDAQ listing guidelines, was performed by the logistic regression analysis for the following related hypothesis:

\section{$<$ Hypothesis 2>}

H0: Korean manufacturing firms belonging to the 'prime' section in the KOSDAQ do not have different mean value based financial ratios from that of their counterparts belonging to the 'venture' section in the same exchange.

H1: Korean manufacturing firms belonging to the 'prime' section in the KOSDAQ do have different mean value based financial ratios from that of their counterparts belonging to the 'venture' section.

The basic functional form of the logistic regression model is as follows:

$\mathrm{P}($ prime section $)=\mathrm{e}^{\mathrm{a}+\mathrm{b} \phi \mathrm{x}} /\left(1+\mathrm{e}^{\mathrm{a}+\mathrm{b} \phi \mathrm{x}}\right)$,

,where $\mathrm{P}$ (prime section) is the probability that a firm will be classified as a member firm belonging to the 'prime' section of the KOSDAQ; this probability is bounded between 0 and 1 .

It labels $\alpha$ and $\beta$ as the intercept and vector of slope parameters, respectively.

$\mathrm{x}$ is a vector of independent variables at each studied year.

The logistic regression is modeling the previously mentioned probability by assigning the dummy variable $\mathrm{SECTION}=1$ (if a firm in the sample was in the 'prime' section) and SECTION=0 (otherwise, that is, the 'venture' section) to the dependent variable. Taking into account the fact that this dummy variable played the role of an independent variable in the previous (first) hypothesis, nine variables with time variables (including or not including the industry dummies), were employed to find some of the financial characteristics which may discriminate between the firms belonging to the 'prime' and the 'venture' section from the financial aspects. (PFT, INSIZE, GROWTH, MVBV, VOLATILITY, MAJORSHARE, FOS, FCF, BETA)

Finally, in this study, since there are so far few research on the tendency to industry mean reversion for the firms listed in the KOSDAQ, it may be very interesting to find any trend or pattern of possible reversion for the sample firms as follows: 


\section{$<$ Hypothesis 3>}

H0: The trend of the capital structure of a firm listed in KOSDAQ is random with respect to its industry mean (or median).

H1: The trend of the capital structure of a firm listed in KOSDAQ is statistically significant (i.e. not random) with respect to its industry mean (or median).

In particular, the methodology to test for the possible reversion was performed in the context of the non-parametric statistical methods, the 'Fisher exact probability' statistic. Taking into account the distribution-free assumption of the non-parametric method, this study also implemented the test for industry 'median' reversion as well as industry 'mean' reversion described above. Fisher theorizes a statistical method which gives the probability of the observed or even more extreme configuration, under the null hypothesis that no directionality exists [36].

\section{Results On the Hypotheses}

\subsection{Analyses and Interpretations}

\subsubsection{The multiple regression results:}

(1) Book-value based leverage ratio as a dependent variable (DV):

1) BVLEV1it $=-2.46^{*}-2.04$ PFTit*

+0.12 INSIZEit* +0.14 GROWTHit*

$+0.004 \mathrm{MVBVit} *+0.0007$ VOLATILITYit*

- 0.0001MAJORSHAREit - (1.51E-13)MVEit*

- 0.0018FOSit* - (2.94E-13)FCFit

-0.034BETAit* -(7.83E-02)SECTIONit*

$+0.02 \mathrm{~T} 2006 \mathrm{it}+(2.03 \mathrm{E}-02) \mathrm{T} 2007 \mathrm{it}$

$+0.027 \mathrm{~T} 2008 \mathrm{it}+(4.86 \mathrm{E}-03) \mathrm{T} 2009 \mathrm{it}$

(Note: * indicates that the independent variable (IDV) is statistically significant at $5 \%$ level.)

2) DIFFBVLEV it $=-2.51^{*}-0.15$ PFTit

+0.10 INSIZEit*+ 0.18 GROWTHit*

$+0.004 \mathrm{MVBVit} *+0.0006$ VOLATILITYit*

+ 0.0003MAJORSHAREit - (1.38E-13)MVEit*

- 0.0005FOSit - (3.18E-14)FCFit - 0.031BETAit

-(8.90E-02)SECTIONit* + 0.03T2006it
$+(1.96 \mathrm{E}-02) \mathrm{T} 2007 \mathrm{it}-0.011 \mathrm{~T} 2008 \mathrm{it}$

- (1.59E-02)T2009it

(Note: * indicates statistically significant at $5 \%$ )

As shown in the above analyses on the book-value based debt ratios, the independent variables such as profitability(PFT), size (INSIZE), growth(GROWTH), market-to book-value of equity (MVBV), volatility (VOLATILITY), market value of equity(MVE) and section dummy (SECTION) showed their statistically significant effects on the book-value based leverage ratios, respectively.

For the purpose of a cross-check, the results of the same dependent variables utilized in the stepwise regression procedures, confirms that 6 out of the total 7 significant explanatory or independent variables indicated above, showed their consistency to explain as the possible determinants of book-value based leverage. (For example, only PFT out of the seven IDVs, was not found to be significant in the stepwise regression.) The time dummy variables such as T2006, T2007, T2008, T2009 did not show their effects as the determinants of capital structure in terms of a statistical meaning. Considering the industry effects on the leverage which showed their conflicting results in the previous literature, the firms belonging to the industry of Publication \& Media (ind4) with a negative coefficient(-), Transportation Equipments \& Parts(ind12) with a positive coefficient(+), Computer Service(ind19) (+), Telecommunication Equipment(ind20)(-), or Transportation(ind24)(-) showed their statistically significant effects as possible characteristics in the stepwise procedures. However, it was surprising that no IDVs showed any statistically significant relationship with the dependent variable (BVLEV2) defined as EBIT/interest expense, in this study.

(2) Market-value based leverage ratio as a dependent variable:

1) MVLEV1it $=-3.80 *-0.29$ PFTit*

+0.17 INSIZEit*+ 0.063 GROWTHit*

+0.0005 MVBVit +0.0006 VOLATILITYit*

+0.0004 MAJORSHAREit -(4.10E-13)MVEit*

- 0.002FOSit* - (2.99E-13)FCFit

-0.091BETAit* -(9.82E-02)SECTIONit*

$+0.01 \mathrm{~T} 2006 \mathrm{it}-(1.84 \mathrm{E}-02) \mathrm{T} 2007 \mathrm{it}$ 


\section{$+0.102 \mathrm{~T} 2008 \mathrm{it} *$ - (6.42E-03)T2009it}

(Note: * indicates that the independent variable (IDV) is statistically significant at $5 \%$.)

2) MDIFFBVLEVit $=-3.72 *-0.13$ PFTit

+0.15 INSIZEit*+ 0.20 GROWTHit*

+0.0010 MVBVit +0.0006 VOLATILITYit*

+ 0.0005MAJORSHAREit - (3.58E-13)MVEit*

- 0.002FOSit + (5.87E-14)FCFit

- 0.092BETAit* - (1.07E-01)SECTIONit*

$+0.05 \mathrm{~T} 2006 \mathrm{it}+(2.54 \mathrm{E}-02) \mathrm{T} 2007 \mathrm{it}$

- 0.032T2008it - (1.90E-02)T2009it

(Note: * indicates statistically significant at 5\%)

Coupled with the test results on the book-value base, the IDVs such as size(INSIZE), growth(GROWTH), volatility(VOLATILITY), market value of equity(MVE), beta(BETA) and section dummy (SECTION) showed their statistically significant effects on the market-value based leverage ratios, respectively. In the stepwise regression procedures to obtain more general interpretations on the test results, 5 out of these total 6 significant IDVs showed their consistency to explain as the possible determinants of market-value based leverage. (That is, VOLATILITY was not found to be significant in the stepwise regression.) The time dummy variables such as T2006, T2007, T2008, T2009 did not also show their significant effects as the determinants of capital structure as in the book-value based test results. Regarding the industry effects on the market-value leverage, the firms belonging to the industry of Transportation Equipments \& Parts (ind12) with a positive coefficient(+), Internet Services(ind18) (-), or Software(ind18)(+), indicated their statistically significant effects as possible financial characteristics as well.

[Table 4] Summary of Regression Results

\begin{tabular}{|c|c|c|}
\hline $\begin{array}{l}\text { Value } \\
\text { basis }\end{array}$ & Leverage & INDs \\
\hline \multirow[t]{2}{*}{ Book } & BVLEV1 & $\begin{array}{c}\text { PFT, INSIZE, GROWTH, } \\
\text { VOLATILITY, MVE, FOS, } \\
\text { BETA, SECTION }\end{array}$ \\
\hline & DIFFBVLEV & $\begin{array}{c}\text { INSIZE, GROWTH, } \\
\text { VOLATILITY, MVE, SECTION }\end{array}$ \\
\hline Market & MVLEV1 & $\begin{array}{l}\text { PFT, INSIZE, GROWTH, } \\
\text { VOLATILITY, MVE, FOS, } \\
\text { BETA, SECTION, T2008 }\end{array}$ \\
\hline
\end{tabular}

\begin{tabular}{|l|c|c|}
\hline MDIFFBVLEV & $\begin{array}{c}\text { INSIZE, GROWTH, } \\
\text { VOLATILITY, MVE, BETA, } \\
\text { SECTION }\end{array}$ \\
\hline
\end{tabular}

(Note)IDVs: Statistically significant independent variables at $5 \%$ level, which were found in the multiple regression results

\subsubsection{The logistic regression results:}

[Table 5] Summary of Logit Results

\begin{tabular}{|l|l|l|}
\hline IDV & Coefficient & Chi-square \\
\hline Intercept & -58.5648 & $170.1745^{*}$ \\
\hline PFT & 5.5347 & $20.9127^{*}$ \\
\hline INSIZE & 2.2647 & $169.5810^{*}$ \\
\hline GROWTH & 0.0524 & 0.0101 \\
\hline MVBV & 0.0494 & $12.6824^{*}$ \\
\hline VOLATILITY & -0.0101 & 2.5830 \\
\hline MAJORSHARE & 0.00468 & 0.7123 \\
\hline FOS & 0.0382 & $8.4783^{*}$ \\
\hline FCF & $5.88 \mathrm{E}-12$ & 2.3413 \\
\hline BETA & 0.2146 & 0.6999 \\
\hline T2006 & 1.1552 & $11.3833^{*}$ \\
\hline T2007 & 1.0311 & $9.0752^{*}$ \\
\hline T2008 & 0.7254 & $4.1307^{*}$ \\
\hline T2009 & 0.3627 & 1.3552 \\
\hline Goodness of Fit & & $552.7594^{*}$ \\
\hline
\end{tabular}

(Note 1)* : Significant at 5\% level with respect to the chi-square test.)

(Note 2) The coefficients were estimated by the method of maximum likelihood (ML). The test for overall goodness of fit was performed by the likelihood ratio (LR) test, while the Wald test was used to test for the significance of each individual coefficient.

The logistic model to test for the second hypothesis of this study, was significantly explained by the seven variables, as shown by the significance of the overall goodness of fit test at the 5\% level. (In other words, PFT, INSIZE, MVBV, FOS with T2006, T2007, and T2008, were significant in the logistic regression results.) All the seven variables were significantly positive, while no variable was significantly negative. Based upon the result, in comparison with the 'venture section', it may be rationalized that the possibilities to be classified into the 'prime section' are higher, when profitability, size, market- 
to book- value of equity, foreign ownership of a firm in the KOSDAQ increase, with the time dummies such as the years of 2006, 2007, and 2008, respectively.

\subsubsection{The Fisher exact probability test results:}

[Table 6] Summary of Fisher Exact Test Results

\begin{tabular}{|c|c|c|c|c|c|}
\hline Leverage & $\begin{array}{c}\text { cell } \\
\text { I }\end{array}$ & cell II & cell III & $\begin{array}{c}\text { cell } \\
\text { IV }\end{array}$ & p-value \\
\hline $\begin{array}{c}\text { BVLEV1 } \\
\text { (mean) }\end{array}$ & 52 & 31 & 26 & 88 & $2.828 \mathrm{E}-08$ \\
\hline $\begin{array}{c}\text { BVLEV1 } \\
\text { (median) }\end{array}$ & 52 & 31 & 26 & 88 & $2,828 \mathrm{E}-08$ \\
\hline $\begin{array}{c}\text { MVLEV1(m } \\
\text { ean) }\end{array}$ & 34 & 23 & 21 & 119 & $1.097 \mathrm{E}-09$ \\
\hline $\begin{array}{c}\text { MVLEV1(m } \\
\text { edian) }\end{array}$ & 33 & 25 & 22 & 117 & $1.787 \mathrm{E}-08$ \\
\hline
\end{tabular}

(Note):

Cell $\mathrm{I}=$ the number of firms belonging to KOSDAQ which are above the industry mean (or median) in the year of 2005 as a base year ,but are closer to the industry mean (or median) after 5 years, the year of 2010.

Cell II $=$ the number of firms belonging to KOSDAQ which are above the industry mean (or median) in the year of 2005 as a base year and move further from the industry mean (or median) after 5 years, the year of 2010 .

Cell III $=$ the number of firms belonging to KOSDAQ which are below the industry mean (or median) in the year of 2005 as a base year that move further from the industry mean (median) after 5 years, the year of 2010 .

Cell IV $=$ the number of firms belonging to KOSDAQ which are below the industry mean (or median) in the year of 2005 as a base year, but are closer to the industry mean (or median) after 5 years, the year of 2010 .

\subsection{Further Investigations and Implication}

The followings are major financial implications or interpretations on the results obtained from the multiple regression models:

Five IDVs showed their consistent and statistically significant effects on the leverage across the two types of measurement of capital structure at book- and market- value bases. In other words, INSIZE, GROWTH, VOLATILITY, MVE, and SECTION are the most explanatory variables to account for as the determinants of leverage.

First, size variable as INSIZE showed its positively significant relationship with the leverage ratios supporting that one of the major hypotheses in finance that large, multi-product firms can carry higher debt ratios than small, one-product firms, since they are generally less-risky, as also tested in Remmers et al.[37]. This traditional rationale to maintain higher debt ratios seemed to be applied to the capital structure strategies implemented by the KOSDAQ firms. Second, the proxy for growth (GROWTH) calculated by using the annual average compound growth rate in sales also showed its positively significant relationship with the level of capital structure, indicating that the firms with higher growth rates may maintain higher debt ratios than their counterparts with lower burden of debt. This positive relationship may not be consistent with Myers' arguments that firms having higher opportunities in investments in intangible assets may face agency costs of debt to a greater degree, as also presented in Kim and Berger[38]. Since firms classified into the KOSDAQ market may be engaged in businesses with relatively high growth opportunities, the results obtained in this study may not be interpreted in the context of the Myers' theory with their higher debt ratios. However, a traditional study by Gupta[39], indicated that growth may be positively related to debt ratio because growth firms may have more flexibility in organizing capital structure, and debt may be more efficient and convenient way to be financed and liquidated than equity funds. Moreover, since the firms listed in the KOSDAQ has relatively narrow capital markets to access in comparison of the firms listed in the KOSPI, this limitation may be one of the reasons to account for the positive relationship between the growth rate and the leverage ratios as found in this study. Third, while in traditional finance theory, a firm with a stable earning stream may maintain higher debt ratios supported by its lower default or bankruptcy risk by keeping the promise on a regular interest payment due, the result on the variable of VOLATILITY relating to the stock returns, showed its positive relationship with leverage, which may not be consistent with the traditional theory. This 
phenomenon may imply that the traditional theory is not fully applicable in implementing the capital structure, due to the relatively short history and immature stage of emerging capital markets including the KOSDAQ as described. Regarding the market value of equity(MVE) the so-called as market-capitalization, it showed its negatively significant relationship with the level of debt. This phenomenon may confirm that firms with relatively high stock prices and/or size in the KOSDAQ market, have more flexibility or choice to access to equity market when raising the capital, in comparison with the firms with relatively small market-capitalization in the domestic market.

Finally, this research found the negative relationship between the dummy variable proxied by SECTION and debt ratio, which indicate that firms belonging to the 'prime' section maintained lower level of leverage than firms belonging to the 'venture' section do. From the perspectives of the firms classified in the 'prime' section, the result may be consistent with the well-known 'pecking order' theory presented in Myers[40]: first, the preference for internally generated funds and, second, the preference for debt over equity if external financing is required. Similar empirical results confirming the theory was obtained by the study of Kim and Berger[41] presenting the negative relationship between profitability and debt ratio for Korean sample firms. However, the result in this study may also suggest an important implication on the firms classified into the 'venture' section. For example, in the theory of finance, firms engaged primarily in venture businesses such as I/T related industries are expected to maintain lower debt burden or ratios to reduce the possibility of bankruptcy. This rationale can be supported by the 'Range of earnings chart' theory which shows the relationship between earnings per share(EPS) and earnings before interest and taxes(EBIT) as presented in Higgins[42] Therefore, as found in this study, it may be worthwhile for managers especially, in the firms classified in the 'venture' section to pay more attention to maintaining a lower level of debt than their counter parties in the 'prime section', when they plan to implement the capital structure policies.

Moreover, the followings are major financial implications on the results obtained from the logistic model: As expected, firms belonging to the 'prime' section with stable earning streams of their relatively mature stage of the business cycles, seemed to maintain higher profitability than their counterparts, which thereby result in the positive coefficient of $\operatorname{PFT}(=5.5347)$. As found in the logistic analysis, the market- to book-value of equity(MVBV) ratio of the firms belonging to the 'prime sector' also showed higher mean value than their counterparts. Firms with higher MVBV in the 'prime section' seemed to be consistent with the result obtained from the previous multiple regression analysis in this study, indicating that firms in the 'prime section' especially maintained lower market-value based debt ratio than their counterparts, due to the higher market value of equity. Finally, the result utilizing the logistic regression analysis demonstrates that, as the proportions of foreign ownership proxied by FOS can be larger, the probability of firms to be classified into the 'prime' section increases, implying that foreign investors (including institutional investors) are currently more interested in investing in the firms with larger-size and higher profitability than investing in the firms in the 'venture' section of the KOSDAQ market.

Concerning implication from the third (null) hypothesis theorizing that the trend of the capital structure of a firm listed in KOSDAQ is random with respect to its industry mean (or median), this study found an interesting result that a firm belonging to each corresponding industry has a tendency for reversion toward its mean as well as median leverage ratios over the tested period ( 5 year). In other words, the leverage ratios of firms listed in the KOSDAQ had a statistically significant tendency to move toward both the industry mean and the industry median over the studied period, based upon both the market- and the book-value. Based upon this result, this study may give an important implication, especially from the perspective of the firms implementing their capital structure strategies, since there are very few research on the reversion of a firm's leverage toward its mean or median ratios in the KOSDAQ market.

\section{CONCLUDING REMARKS}

In this paper, comprehensive theoretical variables tested in finance literature were employed to test for their relationships with capital structure (or leverage) as well as 
to compare the results with those in the previous studies. These explanatory or independent variables were investigated, along with industry classifications and time dummy variables, to account for the book- and market-value based capital structures of the manufacturing firms listed in KOSDAQ during the most recent period from 2006 to 2010.

For the book-value based debt ratios, size(INSIZE), growth(GROWTH), Market to book value of equity(MVBV), volatility(VOLATILITY), market value of equity (MVE) and section dummy (SECTION) showed their statistically significant effects on the book-value based leverage ratios, respectively. Moreover, size(INSIZE), growth(GROWTH), market value of equity(MVE), beta(BETA) and section dummy (SECTION) showed their statistically significant effects on the market-value based leverage ratios, respectively.

This study also found that firms belonging to the 'prime' section may possess the following characteristics identified, in comparison with firms belonging to the 'venture' section: higher profitability, larger size, higher market- to book-value of equity, higher foreign ownership by employing the logistic regression analyses. In addition, historical stock market conditions proxied by time dummy variable seemed to affect the possibility of being a firm classified in either the former or the latter section in the KOSDAQ market, as shown in the previous section. Finally, this study found an interesting result that a firm belonging to each corresponding industry has a tendency for reversion toward both its mean and median leverage ratios over the 5 year tested period.

This study has several weaknesses to be investigated in further research: First, as usually implied, more general results may be obtained by including a wide spectrum of industries and employing the random sampling procedure if data are available. It should also be recalled that the similar or different results obtained from the previous studies in comparison with the findings in this research, might suffer from different measures or definitions of the dependent and explanatory variables, different time periods and methodologies employed. Second, there could be other explanatory variables which might have affected the levels of capital structures for firms listed in KOSDAQ, since the constant term derived from the multiple regression models which represented the average effects of omitted variables, was strongly significant at the $5 \%$ level of significance.

Despite these weaknesses or further research examined, this study may shed new light on the financial issues including the following implications: First, taking into account the higher debt ratios maintained by the firms in the 'venture' section of the KOSDAQ (than those in the 'prime' section) tested in the first hypothesis, firms with shorter history and engaged in the I/T related businesses, may need to lower their debt ratios to reduce the possibility of bankruptcy. This rationale can be supported by the 'Range of earnings chart' theory which shows the relationship between earnings per share(EPS) and earnings before interest and taxes(EBIT). Second, the result tested in the third hypothesis may give an important implication, especially from the perspectives of managers of the firms in KOSDAQ implementing their capital structure strategies, since there are so far, few research on the reversion of a firm's leverage toward its mean or median ratios, as presented earlier.

Since the financial crisis and unstable situations in Korea in late 1997 and 2008, many domestic firms have been restructuring their financial conditions. The results obtained in this study may indicate any new trends of financial conditions of Korean domestic firms, due to the fact that the data were covering the most recent period (2006-2010) and a variety of major explanatory variables were also employed, which can thereby find any new characteristics of the capital structure for the new 'Corporate Korea'.

\section{REFERENCES}

[1] Hanjoon Kim and Paul D. Berger, "A Comparison of Capital Structure Determinants: The United States and The Republic of Korea," Multinational Business Review (16:1) pp. 70-100, 2008.

[2] Vihang R. Errunza, "Determinants of Financial Structure in the Central American Common Market," Financial Management(8:3), pp. 72-77, 1979.

[3] Hanjoon Kim. "Inter- and Intra-leverage Analyses for Large Firms in the United States and Korea," Journal of Asia-Pacific Business (10:1), pp. 34-64, 2009.

[4] Hanjoon Kim and Paul D. Berger, "A Comparison of 
Capital Structure Determinants: The United States and The Republic of Korea," Multinational Business Review(16:1) pp. 70-100, 2008.

[5] Franco Modigliani and Merton H. Miller, "The Cost of Capital, Corporation Finance, and the Theory of Investment," American Economic Review(48:3), pp. 261-297, 1958.

[6] Lee Remmers, Arthur Stronehill, Richard Wright, and Theo Beekuisen,. "Industry and Size as Debt Ratio Determinants in Manufacturing Internationally," Financial Management(3:2), pp.24-32, 1974.

[7] David F. Scott, Jr., "Evidence on the Importance of Financial Structure," Financial Management (1:2), pp. 45-50, 1972.

[8] Norman Toy, Arthur Stonehill, Lee Remmers, Richard Wright, and Theo Beekhuisen, "A Comparative International Study on Growth, Profitability, and Risk as Determinants of Corporate Debt Ratios in the Manufacturing Sector," Journal of Financial and Quantitative Analysis(9:5), pp. 875-886, 1974.

[9] Stewart C. Myers, "Determinants of Corporate Borrowing," Journal of Financial Economics(5:2), pp.147-175, 1977.

[10] Michael G. Ferri and Wesley H. Jones, "Determinants of Financial Structure: a New Methodological Approach," Journal of Finance (34:3), pp.631-644, 1979.

[11] Michael Bradley, Gregg A. Jarrell, and E. Han Kim, "On the Existence of an Optimal Capital Structure: Theory and Evidence," Journal of Finance(39:3), pp. 857-878, 1984.

[12] Robert M. Bowen, Lane A. Daley, and Charles C. Huber, Jr., "Evidence on the Existence and Determinants on Inter-industry Differences in Leverage," Financial Management(11:4), pp. 10-20, 1982.

[13] W. Carl Kester, "Capital and Ownership Structure: A Comparison of United States and Japanese Manufacturing Corporations," Financial Management(15:1), pp. 5-16, 1986.

[14] Sheridan Titman and Reberto Wessels, "The Determinants of Capital Structure Choice," Journal of Finance(43:1), pp. 1-9, 1988.

[15] Michael J. Barclay, Clifford W. Smith, and Ross L. Watts, "The Determinants of Corporate Leverage and Dividend Policies," Journal of Applied Corporate Finance(7:4), pp. 4-19, 1995.

[16] Jun-Hee Cho, "A Study on the Corporate Characteristics between Successful and Less Successful Ventures," Review of Computer Based Accounting(3), pp. 221-234, 2003.
[17] Franck Bancel and Usha R. Mittoo, "Cross-Country Determinants of Capital Structure Choice: A Survey of European Firms," Financial Management(33:4), pp. 103-132, 2004.

[18] Rataporn Deesomsak, Krishna Paudyal, and Gioia Pescetto, "The Determinants of Capital Structure: Evidence from the Asia Pacific region," Journal of Multinational Financial Management(14), pp. 387-405, 2004.

[19] Hanjoon Kim and Paul D. Berger, "The Management Characteristics of Korean Chaebols vs. non-Chaebols: Differences in Leverage and Its Ramifications: Myth or Reality?" Advanced In Management(2:11), pp. 26-35. 2009.

[20] Hee-Jung Park and, Ho-Jung Kang, "Failing Prediction Models of KOSDADQ Firms by using of Logistic Regression," Journal of the Korea Contents Association (9:3), pp. 305-311, 2009.

[21] Hanjoon Kim, "Financial Leverage of Korean Business Conglomerates "Chaebols" in the Post-Asian Financial Crisis," The Korea Academia-Industrial cooperation Society(12:2) pp. 4359-4368, 2011.

[22] Vihang R. Errunza, "Determinants of Financial Structure in the Central American Common Market," Financial Management(8:3), pp. 72-77, 1979.

[23] E. Han Kim, and Y. K. Lee, "Issuing Stocks in Korea," Edited by S. G. Rhee and R. P. Chang. Pacific-Basin Capital Markets Research. Amsterdam: North-Holland, 1990.

[24] S. C. Myers and N. S. Majluf, "Corporate Financing and Investment Decisions When Firms have Information that Investors do not have," Journal of Financial Economics(13), pp.187-221, 1984.

[25] W. Carl Kester, "Capital and Ownership Structure: A Comparison of United States and Japanese Manufacturing Corporations," Financial Management(15:1), pp. 5-16, 1986.

[26] Michael Bradley, Gregg A. Jarrell, and E. Han Kim, "On the Existence of an Optimal Capital Structure: Theory and Evidence," Journal of Finance(39:3), pp. 857-878, 1984.

[27] Hanjoon Kim and Paul D. Berger, "A Comparison of Capital Structure Determinants: The United States and The Republic of Korea," Multinational Business Review (16:1) pp. 70-100, 2008.

[28] Hanjoon Kim and Paul D. Berger, "A Comparison of Capital Structure Determinants: The United States and The Republic of Korea," Multinational Business Review 
(16:1) pp. 70-100, 2008.

[29] Michael J. Barclay, Clifford W. Smith, and Ross L. Watts, "The Determinants of Corporate Leverage and Dividend Policies," Journal of Applied Corporate Finance(7:4), pp. 4-19, 1995.

[30] Stewart C. Myers, "Determinants of Corporate Borrowing," Journal of Financial Economics(5:2), pp. 147-175, 1977.

[31] Michael J. Barclay, Clifford W. Smith, and Ross L. Watts, "The Determinants of Corporate Leverage and Dividend Policies," Journal of Applied Corporate Finance(7:4), pp. 4-19, 1995.

[32] Hanjoon Kim and Paul D. Berger, "A Comparison of Capital Structure Determinants: The United States and The Republic of Korea," Multinational Business Review (16:1) pp. 70-100, 2008.

[33] Robert M. Bowen, Lane A. Daley, and Charles C. Huber, Jr., "Evidence on the Existence and Determinants on Inter-industry Differences in Leverage," Financial Management(11:4), pp. 10-20, 1982.

[34] Caitlin Ann. Greatrex, "Credit Default Swap Market Determinants," Journal of Fixed Income (18:3), pp. 18-32, 2009.

[35] Hanjoon Kim and Paul D. Berger, "A Comparison of Capital Structure Determinants: The United States and The Republic of Korea," Multinational Business Review(16:1) pp. 70-100, 2008.

[36] Robert M. Bowen, Lane A. Daley, and Charles C. Huber, Jr., "Evidence on the Existence and Determinants on Inter-industry Differences in Leverage," Financial Management(11:4), pp. 10-20, 1982.

[37] Lee Remmers, Arthur Stronehill, Richard Wright, and Theo Beekuisen,. "Industry and Size as Debt Ratio Determinants in Manufacturing Internationally," Financial Management(3:2), pp.24-32, 1974.

[38] Hanjoon Kim and Paul D. Berger, "A Comparison of Capital Structure Determinants: The United States and The Republic of Korea," Multinational Business Review(16:1) pp. 70-100, 2008.

[39] Manak C. Gupta, "The Effect of Size, Growth, and Industry on the Financial Structure of Manufacturing Companies," Journal of Finance (24:3) pp. 517-529, 1969.

[40] Stewart C. Myers, "The Capital Structure Puzzle," Journal of Finance(39:3), pp.575-592, 1984.

[41] Hanjoon Kim and Paul D. Berger, "A Comparison of Capital Structure Determinants: The United States and The Republic of Korea," Multinational Business

Review(16:1) pp. 70-100, 2008.

[42] Robert C, Higgins, Analysis for Financial Management (9th ed.), pp. 215-216, McGraw-Hill Co., 2009.

Hanjoon Kim

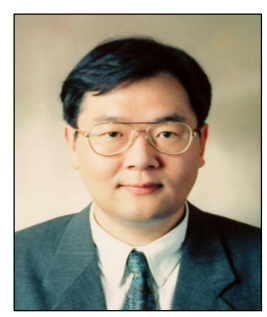

$<$ Research Interests $>$

Corporate Finance, International Finance, Mergers \& Acquisitions, Valuation
- Sept.. 1987 : The George Washington Univ., MBA

- Jan., 1999 : Boston University DBA (Major: Finance)

- Mar. 2010 current : Hoseo Univ. Assistant Professor Dept. of Business Administration,

.

